\title{
Global trends in employment changes and their impact on professionalisation
}

\author{
Galina Bannykh ${ }^{1, *}$, and Svetlana Kostina ${ }^{1}$ \\ ${ }^{1}$ Ural Federal University, Institute of economics and management, School of public administration \\ and entrepreneurship, Mira 19, 620002 Yekaterinburg, Russia
}

\begin{abstract}
.
Research background: Globalization has determined the orientation of transformations in the labour market and employment: on the one hand, blurring of borders has led to an increase in interstate and remote employment (out staffing, freelance), lower costs for the wage fund and increased professional competition for the self-employed, on the other hand, there is an increase in information and digital inequality leading to discrimination in the labour market and high professional mobility of the workforce..

Purpose of the article: The purpose of the article is to analyse and systematize the main trends in the global labour market that affect the process of professionalization of various categories of employees in the Russian Federation.

Methods: As the main research methods there were the analysis of documents, analysis of statistical data, secondary data analysis and expert survey used.

Findings \& Value added: The analysis described global trends in the labour market, as well as their impact on the process of professionalization of various categories of employees in the Russian Federation. Various options for modern professionalization are considered - traditional (based on formal vocational education) and non-traditional. The acquired and relevant professional competencies and professional reputation, rather than the level of knowledge and qualifications, prove to be economic and valuable. The study contributes to the development of the theory of professional socialization and the concept of modern employment, at the same time it can be useful in determining economic policy strategies in the field of labour market and employment regulation.
\end{abstract}

Keywords: global trends; labour market; employment; professionalization; professional socialization; human capital

JEL Classification: $A 14 ; J 01, J 24$

\footnotetext{
* Corresponding author: g.a.bannykh@urfu.ru
} 


\section{Introduction}

New industrialization, digital transformation, the transition to the sixth technological order all these changes of a global nature have put national economies, labour markets, education systems and public relations in front of new challenges. However, these challenges have to be answered in the context of demographic bifurcations (from fertility and marriage rates to migration indicators), the economic crisis, and, more recently, and under special conditions of serious restrictions due to the threat of the spread of the coronavirus pandemic.

We can say that in the modern world, multidirectional and contradictory trends are formed, but their implementation significantly affects the change in labour relations, labour characteristics and the labour market itself. In the context of globalization, these trends, which are manifested with different strengths depending on the nation state or its territory (region), interact, forming global trends that affect the development of various forms of employment, on the transformation of existing forms and structure of professions. The very concept of "profession" acquires new meanings, and the process of professionalization turns into a dynamic and unpredictable one.

Therefore, the authors of the article set themselves the following research problem: to systematize information and knowledge about the existing global trends in employment for the subsequent analysis of their impact on the labour market and profession.

The purpose of the article is to analyse the main trends in the global labour market that influence the process of professionalization of various categories of employed in the Russian Federation.

To achieve this goal, the article sequentially discloses the following questions:

- characteristics of the current state of the global labour market;

- determination of global trends in the global labour market;

- trends in employment in the Russian Federation under the influence of changes in the global labour market;

- features of professionalization.

\section{Methods}

The main research methods in the article are document analysis, analysis of statistical data, secondary data analysis.

The research tools include such methods of scientific knowledge as dialectical, systemic and complex. Logical, comparative and statistical methods of analysis are applied.

The empirical basis of the study was statistical data of the International Labour Organization, official data of the Federal State Statistics Service of the Russian Federation, Eurostat, analytical materials, and sociological research data.

\section{Results}

According to the UN, in 2019, the world labour force was 5.7 billion [1]. Of this total, 2.3 billion (39\%) are not part of the workforce, 3.3 billion ( 57 percent) were employed, and 188 million were unemployed. However, it is worth taking into account the so-called underutilization of the labour force: under the condition of partial or partial employment of those who can work at full strength, as well as the lack of employment opportunities for the unemployed. Indeed, in 2019, the underutilization of the labour force was 473 million, or $14 \%$ of the expanded labour force [2], which is more than double the unemployment rate. So, globalization changes carry tendencies of changes in forms and conditions of employment. 
The main trends in the development of the modern world labour market include the following:

- decrease in employment in professions and specialties associated with routine manual labour and routine cognitive activity. This is due, first of all, to automation and digitalization, the active introduction of robotics and artificial intelligence systems [3]

- changes in the employment rate of older workers [4];

- the rapid spread of flexible (non-standard) forms of employment [5];

- an increase in the influence of such a factor as referral in the number of personnel [6];

- the rapid progress in automation technologies affects the multiple expansion of the information technology sector and business process outsourcing (for example, in India, according to experts, IT companies by 2025 may employ 2.5-3 million more people than they do now [7]).

- large-scale release of the employed, a significant percentage reduction in the share of labour in the gross domestic product [8].

- formation and expansion of the global market for online labour [9]. Related to this, the rapid growth of flexible and independent forms of employment in the context of the active development of digital platforms (freelancers, out staffing, outsourcing, micro entrepreneurship, collective work on crowd platforms [10], etc.),

- the worst position of youth in the labour market (worldwide, more than three quarters (76.7 percent) of working youth work in the informal sector [10]);

- an increase in the skills of the labour force, represented by a change in the role and place of education, including vocational training [11], the emergence of such phenomena as "transfession" and "transfessionalism", which have a significant impact on professional employment.

The platform, sharing economy influences the structure of employment in the global aspect. M. Graham and others talk about the emergence of a "planetary labour market" in digital work [12]. The planetary labour market, in their opinion, is changing the geography of employment, thereby redefining capitalist relations and the structure of employment. Indeed, in this case, we can talk about the impact of digital capital and the digital divide [13]: the less "digital opportunities" people in rural areas and developing countries have, the less opportunities they have for education and professionalization.

A common term for describing the ongoing changes in the sphere of professions and employment is becoming - "transfession". It exists along with generally accepted concepts and denotes the type of labour activity carried out on the basis of the synthesis and convergence of professional competencies from different specialized fields [14]. An employee with a set of diverse competencies from different professional spheres is today most in demand in the labour market precisely because of his transprofessionalism, the ability to perform a wide range of specialized activities.

Transprofessionalism is polyprofessionalism that changes the traditional paradigm of competence and qualifications and allows the formation of a new category of workers. One of the prerequisites for the new category is the mastery of "universal" competences for the new digital economy - digital. However, digital competencies are based on digital technologies, and their change is taking place at an even faster pace, which makes it difficult to unambiguously understand professionalism as the highest degree of mastering professional knowledge and skills [15]. The possibility of realizing intellectual capital with the help of information and communication technologies regardless of place and time is called remote work, or telework. To designate a new category of workers, American researchers T. Malone and R. Loybacher introduced the special term "electronic freelancer" [16].

There are conflicting expert opinions on trends in the online labour market. Thus, F. Malik, B. Nicholson, R. Heeks consider the employment of freelancers as a special form of 
digital work based on an institutionalized ecosystem. This implies the presence of a wide range of stakeholders, including platforms, formal intervention by policymakers and development agencies, and the creation of informal support mechanisms [17]. Thus, freelancing with the support of the state and business entities can play a critical role in the employment sector, especially in developing countries.

There are the high risks of freelancing as a form of employment and the institutionalization of the precariat as a class based on the development of freelancing. Nevertheless, freelancing meets the challenges of the modern information society and its basic requirements for a person and an organization as participants in economic cooperation.

Indeed, flexible forms of employment and its varieties contribute significantly to an increase in the standard of living of the population and a decrease in unemployment. And amid the spread of the COVID-19 pandemic, flexible forms of employment have prevented a global labour market crisis. In total, $94 \%$ of the world's workers live in countries where there is one or another job closure regime [18]. This phenomenon has already received the name - the effect of the coronavirus. Microsoft and Expedia now work from home $80 \%$ of employees, $34 \%$ to $76 \%$ of workers work remotely for Amazon, Uber, Facebook and Google. The uncertainty and inevitability of the next crisis bring precarious work to the fore.

Having considered the main phenomena and trends in the global labour market, let us turn to how these trends manifest themselves in Russia.

The labour force aged 15 and over in January 2020 amounted to 74.8 million people, of which 71.4 million people were classified as employed in economic activity and 3.5 million people were classified as unemployed, meeting the ILO criteria. Global employment cuts due to automation and digitalization in the Russian labour market have not yet taken place. However, experts predict the reduction of about 7 million jobs, which will be compensated for by only 2 million vacancies in new areas of economic activity and the disappearance of up to $10 \%$ of existing professions in the Russian labour market [19]. That is, global trends are manifested in Russia, but at a much slower pace.

In the Russian labour market, there is a large imbalance in the labour force in terms of forms of employment. In 2016, the volume of precarious employment in the Russian Federation ranged from 36 million people (49.7\% of those employed in the economy) - at least to 54.9 million people ( $75.8 \%$ of those employed in the economy) - the maximum [20]. According to the Federal State Statistics Service, the number of people employed in the informal sector of the Russian Federation is currently more than $20 \%$ of the total number of people employed in the economy. According to the Federal Tax Service of the Russian Federation, as of March 2020, about 500,000 self-employed are officially registered.

Precarious employment in Russia is represented in the following contracts:

1. formal direct perpetual contracts and fixed-term contracts with a duration of 1 year or more with the full implementation of the requirements of labour and other legislation by employers;

2. formal direct perpetual labour contracts and fixed-term contracts with a duration of 1 year or more, accompanied by non-compliance

3. employers contract terms;

4. formal contracts accompanying non-standard, flexible and precarious employment of workers: work on the basis of fictitious self-employment, subcontracting, under an agency contract, etc. [21].

Analysing digital platforms for finding a job in precarious employment, one can see the demand for such forms among young people (the average age of a freelancer is 27.8 years), which confirms the global trend. In general, there is also a gender imbalance in the online 
labour market: men predominate among freelancers (more than 77\% work under temporary employment contracts. Analysis of candidates 'resumes and employers' vacancies, you can see the need to develop specific skills among employees, which can be attributed to digital skills. This conclusion also confirms the global trend. Among the many platforms, a large amount of work for freelancing is offered only on one - https://www.fl.ru (contains more than 39,000 vacancies for freelancers).

Of course, the IT sector in the Russian Federation is also showing growth, creating new jobs. And in this direction, the Russian market rather has an inverse imbalance - demand is many times greater than supply. The need for IT specialists is growing as Russia is undergoing a large-scale digital transformation and will only increase in the near future.

As for the consequences of the impact of the pandemic on the Russian labour market, according to surveys by the Center for Labour Studies of the Higher School of Economics, two categories of employed can be distinguished: those who have not been particularly affected by the pandemic (employees of large enterprises in traditional industries, the military-industrial complex, energy, public sector, etc.) and those who were most affected by the pandemic (individual entrepreneurs, medium and small businesses, self-employed and those in the informal employment sector) [22]. In the spring of 2020 , more than $10 \%$ of Russians were transferred to remote work, 1.5 million people were sent to idle work (this is $2.6 \%$ of the working population), 1.3 million are employed part-time or part-time $(2.4 \%$ of all employees) [23].

\section{Discussion and conclusion}

A global trend in the global labour market is digitalization: its consequences are the active formation of the online labour market, a reduction in the supply and workforce in traditional routine industries, an increase in the need for IT specialists, and the formation of transprofessional competencies of potential employees.

National markets have their own specifics of manifestation of global trends. Thus, in the Russian Federation, many of the indicated global trends are manifested, however, unevenly. At a slower pace, the transition to the digital economy and the release of labour due to automation are taking place. However, the most striking trend is the rapid growth of informal employment and flexible forms of work against the background of the active development of digital labour and a decrease in the level of income of the population.

The most common characteristics of the Russian labour market are the decline in the size of the labour force and the working age population (due to demographic factors); in the labour force, the population over the working age is increasing (demographic factors and an increase in the retirement age); the unemployment rate remains low (with high precarious employment); there is a shortage in certain professions (related to the digital economy - big data analyst, programmer, digital architect, etc.).

We thank for financial assistance and support the School of Public Administration and Entrepreneurship of the Ural Federal University.

\section{References}

1. United Nations (2019). World Population Prospects 2019. Retrieved from : https://population.un.org/wpp/

2. International Labour Organisation (2020). World Employment and Social Outlook. Retrieved from : https://www.ilo.org/wcmsp5/groups/public/---dgreports/---dcomm/--publ/documents/publication/wcms_734455.pdf 
3. 3 Vishnevskaya, N. T., Zudina, A. A. (2020). Worker displacement: OECD policies. Mirovaya ekonomika i mezhdunarodnye otnosheniya, 64(7), 17-25.

4. Sullivan, S. E., Ariss, A. (2019). Employment After Retirement: A Review and Framework for Future Research. Journal of Management, 45(1), 262-284.

5. Lepak, D. P., Takeuchi, R., Snell, S. A. (2003). Employment Flexibility and Firm Performance: Examining the Interaction Effects of Employment Mode, Environmental Dynamism, and Technological Intensity. Journal of Management, 29(5), 681-703.

6. Burks S. V., Cowgill B., Hoffman M., Housman M. (2015). The Value of Hiring through Employee Referrals. The Quarterly Journal of Economics, 130(2), 805-839.

7. Woetzel J., Madgavkar A., Gupta S. (2017, June). India's labour market a new emphasis on gainful employment. Discussion Paper. Retrieved from : https://www.mckinsey.com/ /media/McKinsey/Featured\%20Insights/Employment\%20 and\%20Growth/A\%20new\%20emphasis\%20on\%20gainful\%20employment $\% 20 \mathrm{in} \% 2$ 0India/Indias-labour-market-A-new-emphasis-on-gainful-employment.pdf

8. Schwab K. (2016). Teaching in the fourth industrial revolution standing at the precipice. Oxford: Routledge.

9. Pongratz, H. J. (2018). Of crowds and talents: discursive constructions of global online labour. New Technology, Work and Employment, 33, 58-73.

10. International Labour Organisation (2017, November). Global Employment Trends for Youth 2017: Paths to a better working future. Retrieved from : https://www.ilo.org/global/publications/books/global-employment-

trends/WCMS_598669/lang--en/index.htm

11. Hatton, T. (2014). The economics of international migration: A short history of the debate. Labour economics, 30, 43-50.

12. Wood, A., Graham M., Lehdonvirta, V., Hjorth, I. (2019). Good Gig, Bad Gig: Autonomy and Algorithmic Control in the Global Gig Economy. Work employment and society, 33(1), 56-75.

13. Bannykh G. (2020). Digital Capital and the Labour Market: Factors of Mutual Influence. Advances in Economics, Business and Management Research. Proceedings of the International Scientific Conference "Far East Con" (pp. 2946-2953). Vladivostok: Atlantis press.

14. Zeer E., Tretyakova S., Zavodchikov D., Zinnatova M., Bukovey N. (2018). Theoretical Methodological Basics for Studying of Transprofessionalism of a Subject of Socionomic Professions. Eurasian Journal of Analytical Chemistry, 13(1b), em76.

15. Kostina S., Bannykh G. (2019). Features of professional self-determination in the course of life in the digital economy. Proceedings of the 12th annual International Conference of Education, Research and Innovation (pp. 2872-2879). Seville: Iated.

16. Malone T. W., Laubacher R. J. (1998). The Dawn of The E-Lance Economy. Harvard Business Review, 76(5), 144-152.

17. Malik F., Nicholson B., Heeks R. (2017). Understanding the Development Implications of Online Outsourcing. In: Choudrie J., Islam M., Wahid F., Bass J. \& Priyatma J. (Eds.), Information and Communication Technologies for Development. Springer, Cham.

18. International Labour Organisation (2020, June). UN Policy Brief: The World of Work and COVID-19. Retrieved from

https://www.ilo.org/employment/Informationresources/covid-

19/other/WCMS_748323?lang=en 
19. Federal State Statistics Service (2020, January). Employment and unemployment in the Russian Federation in January 2020 (based on the labour force survey). Retrieved from : https://rosstat.gov.ru/bgd/free/B04_03/IssWWW.exe/Stg/d05/34.htm

20. Precarious employment in the Russian Federation: theory and methodology for identification, assessment and the vector of reduction (2018). Moscow: KNO-RUS.

21. Bobkov V. N., Odegov Y. G., Garnov A. P. (2018). Precarious Employment in the Regions of Russian Federation: Sociological Survey Results. Ekonomika regionaeconomy of region, 14(2), 366-379.

22. Gimpelson B (2020, September). How the coronavirus changed the labour market Retrieved from : https://vtimes.io/news/kak-koronakrizis-izmenil-rynok-truda

23. Kovalenko A. (2020, June). Who the labour market needs. Expert. Retrieved from : http://www.acexpert.ru/articles/kto-nuzhen-rinku-truda.html 